\title{
Reforming police: Opportunities, drivers and challenges
}

Final draft of paper subsequently published as:

Stenning, P. C., \& Shearing, C. D. (2005). Reforming police: Opportunities, drivers and challenges. Australian \& New Zealand Journal of Criminology, 38(2), 167-180.

Online: http://anj.sagepub.com/content/38/2/167.full.pdf

\begin{abstract}
A few years ago, David Bayley and Clifford Shearing (1996) argued that at the end of the 20th century we were witnessing a 'watershed' in policing, when transformations were occurring in the practices and sponsorship of policing on a scale unprecedented since the developments that heralded the creation of the 'New Police' in the 19th century. In this special issue of the journal, we and our fellow contributors turn our attention to a somewhat neglected aspect of this 'quiet revolution' in policing (Stenning \& Shearing, 1980), namely the nature of the opportunities for, and challenges posed by, the reform of policing in different parts of the world at the beginning of the 21st century. Our attention in this issue is particularly focused on the opportunities, drivers and challenges in reforming public (state- sponsored) police institutions.
\end{abstract}




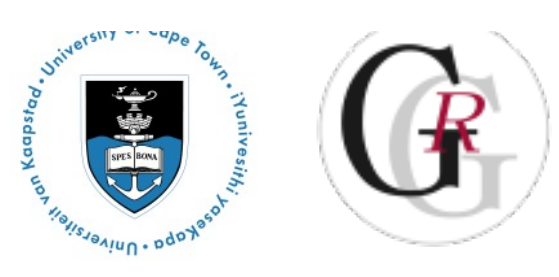

By now, it will probably be unnecessary to remind our readers that when we speak of 'policing', we have in mind a lot more than just what familiar public 'police forces' and 'services' do. Rather, we are referring to a societal, and increasingly global, ordering function that nowadays is carried out by an increasingly wide and diverse array of state, suprastate and nonstate organisations under equally diverse sponsorship. The transformations that have been occurring in 'policing' in this broad sense have involved a series of shifts not only in who does policing, and under whose authority and sponsorship, but also in how those who do it conceive of the task of policing itself, and how they go about getting the job done (Bayley \& Shearing, 2001). So we have witnessed a shift from a state near-monopoly (or at least a claimed monopoly) over policing policy and provision to a situation of plural or 'nodal' governance of it, involving in turn a shift through partnership to networks (Baker, 2005; Crawford et al., 2005; Hermer et al., 2005; Johnston \& Shearing, 2003, ch. 8). The focus of policing, moreover, has been shifting from an emphasis on crime control and law enforcement to an emphasis on broader goals of security, safety and harm reduction and prevention. And this in turn has led to a shift from after-the-fact, morally driven 'banditcatching' to a more obviously instrumentally inspired preemptive, preventative approach to the task of policing (Shearing \& Stenning, 1982; Stenning et al., 1990).

One of the most interesting features of these developments, from a public policy point of view, has been the seemingly quite haphazard and unplanned, uncoordinated way in which they have most typically occurred. Absent any preeminent authority with the capacity to dictate the direction and pace of policing reform, transformations appear to be the product more of largely unseen (or at least often not very clearly seen) economic, political, social and cultural 'forces' and influences at work in the background. While a variety of theories about the determinants of these changes have been proffered (see, e.g., Jones \& Newburn, 1998, ch. 2, for a review of some of these), these have mostly been devoted to explaining developments in advanced capitalist western (and usually English-speaking) democratic states such as the United States, Britain, Canada and Australia.

All these developments have potentially profound implications for public, state- sponsored policing institutions. So in this special issue our aim has been to broaden this inquiry and to pose some quite fundamental questions in a more global context. Specifically, we asked the contributors to this special issue to consider what kinds of factors have been facilitating and inhibiting the kinds of transformations in public policing institutions that have been occurring to varying degrees, and at different paces, in a variety of countries and regions of the world. Put another way, what factors can be identified that create significant opportunities for reforms of public police institutions? What factors and trends have been driving such reforms, and are likely to do so in the future? And what are the principal challenges facing those who seek to achieve such reforms or transformations? 
In order to gain as diverse a range of perspectives on these questions as possible, we deliberately invited scholars from a range of different countries and regions of the world, reflecting widely different systems and ideologies of government and cultural traditions, to contribute to this special issue. While the space constraints of a single issue of a journal have inevitably forced some unwelcome selectivity on us in this respect, we are nevertheless satisfied that the range of different perspectives on the topic that have been captured in the articles that follow allows for a significant enhancement of our understanding of how and why transformations in policing occur in some places but not in others, and what reforming public policing institutions involves in different contexts and at different times.

It may be helpful to think of these opportunities and challenges in terms of internalities (conditions within institutions that provide policing) and externalities (conditions within the external environments within which such institutions operate) that are conducive or otherwise to policing reform. So let us briefly review some of these.

\section{Opportunities and Drivers}

\section{Externalities}

The last years of the 20th century, and the early years of the 21st have been a period of great geopolitical upheavals around the world. With the collapse of communist regimes, particularly in Eastern Europe and Asia, and the fall of many totalitarian regimes in many other countries in the world, there has been a veritable host of countries 'in transition' (usually towards more democratic institutions of governance, and from centrally controlled to more 'open' market economies) that are in various stages of radically transforming or reinventing their policing provision. This, as Bayley illustrates in his article in this issue, has given rise to a veritable policing reform 'industry', in which technology transfer and assistance has become an instrument, as often as not, of donor countries' domestic foreign policy. While the United Nations has also, of course, played a key role in restoring essential policing provision in many of these situations, the whole business of 'foreign aid', 'international assistance' and 'peacekeeping' has inevitably raised questions about whose interests are really being served by such interventions, and whether the various policing arrangements that are being exported and imported are really appropriate for the receiving countries. For those in the business of 'police reform' in particular, as well as 'governance' reform more generally, however, the current era could understandably be regarded as a golden age.

Hand in hand with this geopolitical repositioning has been an ideological refocusing that emphasises the need for policing not only to be 'culturally appropriate' but also 'democratic' and respectful of fundamental human rights (Cohen, 1993). This has forced a reconsideration not just about the technologies of policing, but also of the acceptability of orders that providers of policing are being asked to police. Acceptable policing, it is argued, is not just 
policing that efficiently and effectively polices a prescribed order,

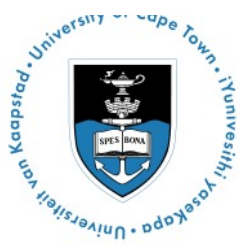

but policing that conforms with internationally accepted norms of civility, dignity and human rights (Hermer et al., 2005).

There is, thus, along with economic globalisation, a growing trend towards international 'harmonisation' of policing standards and practices which is most commonly characterised by reference to 'best practices'. ${ }^{1}$

Alongside these international upheavals and transformations, some major transformations have been occurring within established democracies with long-established and stable policing arrangements, that are driving policing reform. Among these, we can readily identify transformations in the character and uses of property (what we have earlier characterised, borrowing from Spitzer and Scull [1977], as the modern development of 'mass private property'; Hutchinson \& O'Connor, 2005; Kempa et al., 2004), increasing population migration (transforming domestic populations into increasingly multicultural societies; Erez et al., 2003), and demographic trends leading towards increasingly 'older' populations while at the same time producing booms and 'echo booms' in the traditionally 'crime-prone' age group (Foot, 1996). Add to these trends the exponential development of new technologies that simultaneously generate new policing problems and new policing 'solutions' (Chan, 2003), and it can come as no surprise that policing providers find themselves under growing pressures to enhance, upgrade and 'reinvent' themselves.

Alongside these broader social and international trends, policing providers are nowadays being expected to adapt to changing approaches towards the content and delivery of 'justice' to which, among other goals, their efforts are expected to contribute. Increasingly, the traditional relationships between policing and formal criminal justice systems and institutions are being called into question, and alternative responses to the kinds of problems that have been the major focus of policing are being advocated and tried. Diversion from criminal justice processing and conceptions of 'restorative' rather than retributive justice are the most prominent manifestations of such rethinking about the ends to which policing should be directed (Strang \& Braithwaite, 2001).

\section{Internalities}

Within policing organisations themselves, various developments are occurring that are either providing significant opportunities for reform, or are creating demands for it. Under increasing pressure from their government sponsors to be more efficient, cost-effective and

\footnotetext{
${ }^{1}$ See, for example, the web site of the Centre for Problem-Oriented Policing in the United States: http://www.popcenter.org/
} 
accountable, police services began to transform themselves.

Traditional police 'command and control' approaches to management began to give way to managerialist approaches prevalent in the private sector (McLaughlin \& Murji, 2001). As with other public services, public police organisations began to see themselves as service organisations (reflected in a change in nomenclature from 'police force' to 'police service'; Avery, 1981) providing a service (product, 'output') for their 'client' governments and 'communities'. And public police found themselves competing with other potential policing providers, both in the public and private sectors, for the resources and 'contracts' to provide these policing services (Rigakos, 2002, pp. 153-157; Wood, 2000). Police services were required to enter into 'purchase agreements' with their government sponsors (Chan, 1999), just as their private sector competitors had always been required to do with their clients. Instead of having indefinite tenure, police chiefs and commissioners became parties to limited-term contracts and 'performance agreements' that were strictly audited by their employers. Their performance, and that of the organisations they led, were subjected to a growing array of accountability mechanisms, including enhanced public complaint processes, more open budget processes, community-based and interest group consultative committees of various kinds, and increasingly demanding reporting requirements, all in the context of a general trend towards 'freedom of information' (Jones, 2003; Walker, 2005).

Alongside these organisational demands for change, the 1980s and 1990s saw a radical rethinking of what public policing is all about and how it should be done. 'Community policing' or 'community-based policing' became the prevailing mantra for police services around the world, requiring them to develop completely different relationships with the 'communities' that they policed (Brogden \& Nijhar, 2005). In time this led to other ideas about how policing can best be accomplished, variously labelled 'intelligence-led', 'evidence-based' and most recently 'reassurance' policing (Tilley, 2003; http://www.reassurancepolicing.co.uk/).

All these developments generated the need for enhanced resources, both technological and human, for policing, and a police labour force with entirely new skills and mindsets. Increasingly, police officers needed to have enhanced communication skills, enhanced technological, managerial and leadership competencies, and enhanced political skills. Fortunately, the historical demographics of police organisations themselves came to the rescue.

The post-World War II years in the 1950s and 1960s, particularly in western democracies, saw the 'baby boom' that greatly increased the proportion of the population that was in the traditionally 'crime-prone' age group (16-24), and consequently great increases in reported crime (Linden, 1989, 2000). States responded to this by significantly increasing their investment in public police forces, so that in many countries the numbers of police officers doubled or even tripled in these decades. But the economic recession that followed in the 1970s and early 1980s (the era in which 'do more with less' became the most common governmental mantra) brought a sharp halt to this expansion, and recruitment of new police 
officers was in many countries brought almost to a standstill. The

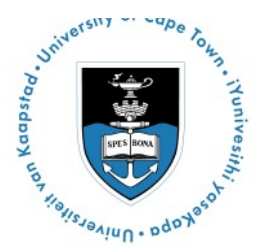
result was that in the 1990s, many of those in the 'old guard' of police services (i.e., those who had joined the service during the 1950s and 1960s) began to retire in large numbers, leaving a significant middle management deficit as a result of the lack of recruitment in the 1970 s and 1980s. While many police services characterised this as a human resources crisis, it can equally be seen as providing a unique opportunity for reform of the police labour force - replacing the 'old guard' with a new breed of police officer who had grown up in police service with very different ideas about what policing is all about and how it should be done ('community-based' policing had become the dominant ideology of police services around the world during the 1980s and 1990s), and with very different ideas about what a 'career' involves. Recruits to police services in most Western democracies during the 1990s tended to be older (typically in their late twenties rather than their late teens), more mature, better educated (by the end of the 1990s most had completed high school and had some college education), were more frequently married with families, and frequently had prior work experience other than in policing. The 'raw material' for doing policing was thus quite significantly transformed (see, e.g., Ontario, Strategic Planning Committee on Police Training and Education, 1992).

Another significant driver of reform during the last thirty years or so has undoubtedly been the competition that the resurgence of private and other nonstate policing has engendered. The private sector in particular has generated new models, approaches and tools for policing that have forced the public sector to 'raise its game'. In turn, the need to achieve legitimacy and respect has forced private sector policing organisations (the 'private security industry') to raise its standards of professionalism, integrity and commitment to 'the common good' rather than just to profit. And for both the public and private sector, the development of viable and productive partnerships has become an inescapable imperative (Richardson, 2000; Shapland \& Van Outrive, 1999).

Finally, and unfortunately, it cannot be denied that scandals - of which the Rodney King affair in the United States and the Stephen Lawrence saga in the United Kingdom are perhaps the best known recent examples - have played an important role as drivers of reform (Sherman, 1978). The inevitable political sensitivity of so much policing is such that some such scandals, and the resultant pressures for reform, have occurred in almost every jurisdiction (Prenzler, 2002). 


\section{Challenges}

\section{External}

Even with the best will in the world, those who seek to reform policing frequently face substantial challenges and obstacles. In many countries of the world still, these take the form of an enduring culture and history of corruption, of dominance by partisan interests, and of other reform priorities that understandably are given precedence over reform of policing. Reforming policing is neither inexpensive nor easy and, absent the necessary political will and commitment, will rarely be successfully accomplished.

In many countries, corruption and its common progeny, poverty, continue to render reform of policing, and removal of obstacles to it, unachievable. Police officers who are not paid enough to look after themselves and their families, and are not provided with essential resources (vehicles and/or petrol, for instance) for effective policing, inevitably resort to corruption and other assorted forms of deviance, including brutality and extrajudicial 'justice', to supplement their incomes and satisfy the demands of their superiors and political masters (see, e.g., Chukwuma, 2005; Frank \& Tait, 2005; Harriott, 2000; 'Law-Enforcers on the Rampage', 2005; Wong, 2004). Improving the quality of policing in such circumstances can be a very dificult task, for obvious reasons.

Countries 'in transition' that have only recently emerged from major conflict, civil wars or authoritarian regimes are often poorly placed to achieve effective reform of policing without a lot of outside assistance and support. Even when this is available, legacies of enmity and mistrust can easily derail even the most genuine reform efforts. Proponents of reform are often no more trusted than the police they seek to reform (Hinton, 2005).

Even in countries that do not face such obstacles, however, achievement of significant reform of policing is often hindered by a lack of understanding or acceptance, by politicians and the public more generally, of any need for it. Old ideas (e.g., that policing is a matter solely for the public police) die hard, and without public support reform initiatives often cannot get off the ground. And in this respect the media, from whom both politicians and the general public derive so much of their understanding of policing issues, can often inhibit as much as encourage reform efforts.

Simply keeping up with new forms of crime, such as cybercrime (Wall, 2002), often poses huge challenges for reforming policing, and in this respect it is no surprise that public police institutions as often as not find themselves following the lead of the private sector, rather than leading themselves. The more substantial resources of nonstate sponsors of policing, for instance, typically allow them to invest in new forensic technologies more quickly and more substantially than their government counterparts. 


\section{Internal}

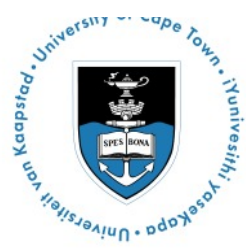

Despite the demographic changes that have occurred within many police services, many are still led by senior officers of the 'old school', who joined the service in the 1960s and early 1970s when attitudes to police work and police leadership were very different than they are today. Within many police organisations, therefore, there remains considerable resistance to progressive change, which is not infrequently echoed by conservative leaders of police associations and unions. In particular, the view that public police are the only people who can and should be entrusted with the job of policing, and that any innovations in policing must be with the agreement, and under the direction, of the public police, is still prevalent.

Many public police officers still regard private security organisations as both inferior and inherently suspect (or worse, infiltrated by the criminal element; Shearing, Stenning, \& Addario, 1985; and see, e.g., Kinnear, 2000), which makes the building and maintenance (or at least any public recognition and acceptance) of good public-private policing partnerships difficult. And such attitudes persist despite the fact that many, if not still most, of the leaders of private security organisations are themselves former members of public police services. Such partnerships thus commonly flourish informally while not being publicly acknowledged or approved. Police associations and unions in particular, and perhaps quite understandably, resist and decry privatisation of functions and services that have, for the last 150 years or so, been regarded as the more or less exclusive preserve of public police (Obst, 2000, p. 82). And even within the public sector, 'turf wars' ver policing functions between different organisations are not uncommon ${ }^{2}$.

An ideology of 'police independence', according to which any political direction of the public police is presumptively suspect and undesirable, continues in many countries to underpin police resistance to politically directed reform initiatives that do not command police support. Despite a theoretical division of authority between 'policy' (regarded as a legitimate sphere for political direction) and 'operations' (within the exclusive authority of the police themselves), the 'operational' sphere is still interpreted very broadly by many police leaders, leaving the police budget (and even then only in the most general terms) the only legitimate subject for political determination (Stenning, in press).

From this very brief review, it will be evident that the drivers, motives for, and commitment to reform of public policing institutions, and the balance of opportunities and challenges for

\footnotetext{
${ }^{2}$ Although sometimes such apparent conflicts really reflect differences in mentalities (Johnston \& Shearing, 2003, chs. 3-5), approaches, mandates or objectives among different agencies, rather than competition or conflict as such: see, for example, Geddes, 2005.
} 
such reform, vary greatly from one context to another. Our aim in

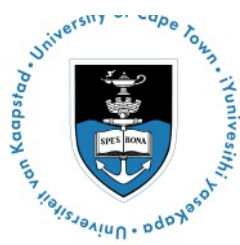

this special issue is to explore the extent and nature of this variation in more detail than has been done up to now.

It will also be obvious that when it comes to reform of policing, timing is usually everything. When (and why) the right conditions for reform will arise in any jurisdiction has been difficult to understand or predict. Another of our aims, therefore, has been to try to render such matters more readily knowable.

What has been reasonably clear for sometime, however, and what largely motivated us to propose this special issue, is that the beginning of the 21st century appears to offer unprecedented opportunities for such reforms. In fact, as many of our contributors illustrate, the opportunities for reform of public policing institutions around the world may be greater now than they have been since the radical reforms of such institutions in the early 19th century. The challenges for reform, however, must not be underestimated.

Each of the contributors to this volume has picked up on one or more of the themes we have reviewed. What is evident from their contributions is the fundamental importance to policing reform of the particular historical and contemporary context in which it takes place. One message of the collection is that while context might not be everything it is vitally important as it shapes the drivers, opportunities and challenges. One of the features that shapes context and makes it so important is that reform is always a contested terrain with differing visions of reform and a variety of sources of resistance to any particular reform vision. One consequence of this recognition is that it makes clear that one cannot understand reform simply through a focus on mentalities that shape governance - no matter how important they might be. Reform is shaped by context because people and circumstances matter agency matters.

Kempa and Johnston, in exploring reform in the context of the United Kingdom, remind us that we live in an era of plural policing and that this is increasingly becoming a central concern of state police agencies. One way in which this concern is being expressed is through the question: How should police locate themselves within this plural context of multiple policing agencies and multiple sources of direction in policing? This question was forcefully raised in the United Kingdom in 1998 by lan Blair, now Commissioner of the London Metropolitan Police, who argued back then that the question, 'Where do the police fit into policing?', should be on the police policy agenda (Blair, 1998). An important answer to this question is now being developed by governments and police organisations within the United Kingdom.

Kempa and Johnston report on two initiatives that provide and seek to realise a state response to plural policing. One of these is being driven by the London Metropolitan Police as part of a wider move within the United Kingdom to include within the police organisation - or as it is being called in the United Kingdom, the 'police extended family' - functions that 
other policing agencies have been fulfilling through the employment of 'community service officers', within police organisations. This is a clear response by the police and governments to the nodal nature of the governance of security. In Kempa and Johnston's words 'Blair's "high political” overtures had unambiguously partisan aims: to secure MPS [Metropolitan Police Service] control over London's plural policing networks and, if possible, to put the opposition - both municipal and commercial - out of business in the process'.

The second initiative they explore is one that was initiated in 1999 with the publication of the proposals of the Independent Commission on Policing for Northern Ireland (1999: the Patten Commission). They consider both the proposals and the way in which the United Kingdom government has responded to them.

The Patten proposals called for the development of governance structures at the macro level that viewed policing as a whole and suggested ways of regulating the various auspices and providers engaged in the governance of security. What Kempa and Johnston propose is that, in responding to the challenges of nodal policing, what is required are 'leaps of imagination' fostered though deliberative arrangements that will bring people together to explore new regulatory possibilities.

In considering context, one of the issues that the papers in this volume highlight is the importance of the history of policing reform. While this theme cuts across all the papers, it is one that Fleming and Rhodes have made a focus of their analysis. They do so by exploring the implications of the fact that reform processes leave in their wake deposits that continue to influence the way in which policing takes place long after they are an explicit focus. This is something that Wood (2000) refers to in earlier work with the metaphor of 'waves', which create structural tensions that are experienced as a need for 'alignment' (Deukmedjian, 2002, 2003; see also Leman-Langois, 2000, 2002). Like Brodeur, Fleming and Rhodes point to a reality of 'constant reform'. The constant nature of reform has its roots in the tensions that arise as new reform agendas are layered onto older ones. This, they argue, 'renders all reforms contingent'.

What will determine the future of police organisations, they argue, is not the models of governance - bureaucratic, contractual, networked - that are in ascendance at any particular moment but the way in which the elements of the variety of models that have guided reform are related. Within this framework, the challenge of police reform ' will be the efforts to match management style to the situation, to balance the unholy trinity of the everchanging mix of markets, hierarchies and networks'.

David Bayley takes up the theme of how to promote reform that recognises the importance of context but at the same time that there are indeed general lessons to be learned. He argues that it is possible to articulate these lessons and to create guidelines that can assist reformers 
to learn from past experience. A key ground for optimism that this position embraces is the extent to which a consensus has been forged across the globe with respect to the nature of democratic policing - a consensus that Bayley articulates in terms of seven basic principles.

This is particularly important, he argues, because since the 1990s a window of opportunity for policing reform has arisen in a variety of countries across the globe as autocratic governance regimes have been challenged by more democratic possibilities. Bayley raises this challenge within the context of a number of reform initiatives that are now taking place across the world. One feature of this, Bayley notes, is that policing has become an objective of the foreign policy of many governments. In addition, there is now a sizeable number of international agencies that are engaged in the reform of policing, the provision of policing advisors on the ground and the provision of police to assist in creating viable policing organisations and to help drive and shape reform in other countries. Bayley points to the existence of a tension between efforts to promote democratic reforms (including democratic policing) and the necessity of maintaining law and order through the building of effective lawenforcement capacities.

Despite his optimism about the possibilities of international aid in assisting with policing reform, Bayley cautions that such assistance 'can only facilitate changes in the character of local policing'. In reviewing the impact of international efforts to facilitate in this way, Bayley identifies lessons gleaned from shortcomings in efforts to date. Crucially he notes that it is important to move beyond goals to 'specifying the particular actions that achieve those goals'. He also cautions against separating issues of efficiency from ones of fairness and emphasises the importance of moving simultaneously on both fronts. Finally, he draws attention to the importance of evidence in policing reform. This, he argues, is an essential ingredient for accountability, and one that will move police organisations beyond a situation where management is by myth, to a 'new management style' that is evidence-based.

The next three papers in the collection focus on particular cases of policing reform. They each explore, in different ways, some of the evidence and arguments we have highlighted here. In doing so they weave a rich tapestry of the realities of policing reform on the ground realities that are replete with drivers, opportunities and challenges. Costa and Nield in their analysis of reform in Latin America generally, and Peru in particular, point to the difficult challenges that are faced when the police organisations involved have a long history of corruption and abuse. In these contexts, they note the importance of deeply embedded vested interests that support these practices and the difficulty that this presents to any attempts designed to reshape these organisations. They note how these interests - which are often very varied - can, and do, successfully undermine reform processes.

In the course of their analysis they take up the theme of context and the difficulties of adapting reforms and reform strategies to different contexts. Like Bayley, they identify 
international support as an important facilitative factor in reform.

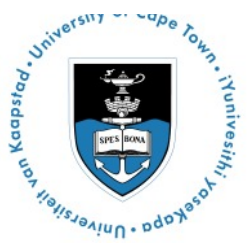

Ultimately, however, they argue it is political will and capacity that are vital.

Both Solomon, writing about reform in Russia, and $\mathrm{Fu}$, whose paper is on police reform in China, point out that a central concern of reform has been the relationship between police and the polity - that is, the issue of political location and control. Solomon argues that it is not always conceptions of good policing that drive reform. Often it is larger political questions and political conflicts that are the primary motivators and levers of the reform process. Reform often takes place as part of larger processes of political conflicts. When this happens, police reform follows the contours of these larger developments.

In exploring these issues, Solomon takes up the question of the pluralisation of policing that has been an important consequence of the break-up of the Soviet Union. In Russia, Solomon notes, 'not only was there a proliferation of all kinds of private security services, but the regular police themselves began doing contract work, inside and outside the law'. There are clear resonances here to Fleming's and Rhodes' discussion of the tensions that exist between bureaucratic and contract states. Much of this tension, Solomon notes, had its roots in the essentially political issue of budgetary allocations. In exploring this issue, he reports on data that show that the 'Russian police receive more income from nonstate actors than from state budgets'. As the paper by Kempa and Johnston makes clear, this 'commodification of the public police' (to use Solomon's phrase) is widespread. However, in Russia this commercialisation may have served to fundamentally 'reduce the effectiveness of basic police services'. A pervasive theme of Solomon's contribution, however, is that it is not single issues that are critical but the range of issues confronting Russian policing that makes the task of reform so daunting.

In his contribution, Fu takes up the point we mentioned in connection with Fleming and Rhodes' contribution, and that Brodeur emphasises in the title of his piece, namely, that reform programs 'have become a constant, perpetual and permanent feature of the police in post-Mao China'. The critical contextual issue for Fu in understanding this perpetual reform is that change is taking place not in a democracy, or even a society that presents itself as moving in a democratic direction, but in a one-party state.

In his analysis of drivers of reform, Fu takes up a theme that Sherman drew attention to decades ago, namely, the importance of scandal for reform (Sherman, 1978). Scandal has been a significant motivation in China. In responding to scandals, an important line of argument has been what Fu calls the 'people factor' - that is, reforms that focus on 'education, characteristics and quality of police officers' - in explaining, and seeking to remedy, abuse of power. Here Fu here takes up an issue that has a long history in the literature of reform, namely, the tendency of police organisations to focus on bad apples rather than bad barrels (Shearing, 1981). It is the bad barrels, or the 'institutional factor', that $\mathrm{Fu}$ argues has been the focus of rank-and-file officers when they seek explanations for 
problems in the police organisation. A more critical view of the

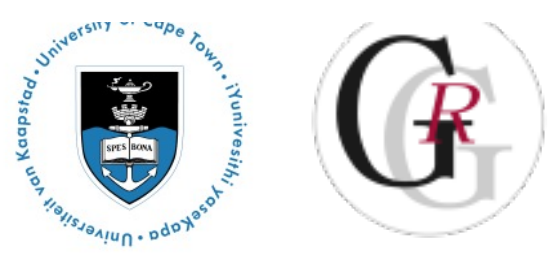
sources of police abuse and corruption, and one that Fu argues is held by 'dissidents, liberal scholars and some police officers', is that the roots of the problem lie with the 'special political status of the Chinese police and their intimate relationship with the ruling $\mathrm{CCP}^{\prime}-$ a view reflected most recently in Lord Ashdown's comment, in the context of Bosnia, about how vital to police reform it is to break what he calls 'the nexus of politics, crime and the police' ('Bosnia's Government', 2005).

The theme of 'permanent police reform', as we have noted, is one that Brodeur takes up in his contribution. He argues that reform mentalities have been quite curiously focused on 'patrol persons in uniform'. However, at the same time as these more public reform agendas are being pursued, Brodeur argues, there are often other agendas that, while they may not be labelled publicly as reforms, often bring about profound changes that are at odds with the explicit reform agendas. This theme of 'unforeseen changes that often outlast planned reforms' resonates with the Fleming and Rhodes analysis of the tensions that different waves of reform create.

For Brodeur the events of 9/11, and the terrorism threat that they have brought to the fore, constitute a huge contemporary driver of change that is going to reshape policing and that could well turn the clock of change back considerably. This might well, he suggests, be one of the factors that will, and already is, reshaping the police in ways that will recreate more militaristic police organisations. In Brodeur's terms, police organisations are 'increasingly getting into ... the 'high policing' gear'. This is 'bringing back the police to their traditional call of coercively managing people in dangerous physical crises'. Terrorism, he surmises, may turn out to be the monster that ate criminal justice.

This argument that reform should not be thought of as a linear process moving in one direction - that it is, in Fleming's and Rhodes' terms, contingent - is a theme which is central to the last paper in the collection. However, the sources of the return to a more traditional police conception in the Netherlands that Punch, Hoogenboom and Williamson trace are not the sources of high policing that Brodeur identifies. What Punch et al. identify is a 'constellation of general external factors and specific domestic factors' that are placing the paradigm of policing founded on compromise and tolerance, for which the Dutch police have become so well known, under stress. They conclude that:

The unique Dutch paradigm came at a specific time and a humane, tolerant and caring society produced a humane, tolerant and caring style of policing. But when major external developments, significant political pressure and, above all, a society shift to the right within the Netherlands threatened once more to outflank them, the Dutch Police effectively relinquished their paradigm. 
If this reversal could happen to Dutch policing, where the tolerant paradigm of community-centred policing seemed to be so secure, this suggests that similar reversals could also happen elsewhere. This provides grounds for both optimism and pessimism: optimism because it means that change is possible even in the face of mentalities and practices that appear deeply rooted and unchangeable; pessimism because it suggests that what are regarded as well-entrenched progressive changes can be short lived.

\section{References}

Avery, J. (1981). Police: Force or service? Sydney, Australia: Butterworths.

Baker, B. (2005). Multi-choice policing in Uganda. Policing \& Society, 15(1), 19-41.

Bayley, D., \& Shearing, C. (1996). The future of policing. Law \& Society Review, 30(3), 585606.

Bayley, D., \& Shearing, C. (2001). The new structure of policing: Description, conceptualization, and research agenda. Washington, DC: US Department of Justice, National Institute of Justice.

Blair, I. (1998, July 16). Where do the police fit into policing? Unpublished paper presented at ACPO conference, UK. Available from the authors.

Bosnia's government: Political stalemate. (2005, June 11). The Economist, 50.

Brogden, M., \& Nijhar, P. (2005). Community policing: National and international models and approaches. Cullompton, UK: Willan.

Chan, J. (1999). Governing police practice: Limits of the new accountability. British Journal of Sociology, 50(2), 251-270.

Chan, J. (2003). Police and new technologies. In T. Newburn (Ed.), Handbook of policing (pp. 655-679). Cullompton, UK: Willan.

Chukwuma, I. (2005). The future of police reform in Nigeria. In Open Society Institute, Justice Initiatives - Human Rights and Justice Sector Reform in Africa: Contemporary Issues and Responses (February 2005, pp. 12-14). Retrieved June 14, 2005, from http://www.soros.org/resources/articles_publications/publications/justice_20050207/Justice_africa.pdf

Cohen, S. (1993). Human rights and crimes of the state: The culture of denial. Australian and New Zealand Journal of Criminology, 26, 97-115. 
Crawford, A., Lister, S., Blackburn, S., \& Burnett, J. (2005). Plural

policing: The mixed economy of visible patrols in England and Wales. Bristol, UK: The Policy Press.

Deukmedjian, J. (2003). Reshaping organizational subjectivities in Canada's national police force: The development of RCMP alternative dispute resolution. Policing \& Society, 13(4), 331-348.

Deukmedjian, J. (2002). The evolution and alignment of RCMP conflict management and organizational surveillance. Unpublished doctoral dissertation, University of Toronto, Canada.

Erez, E., Finckenhauer, J., \& Ibarra, P. (Eds.). (2003). Special issue: Policing a multicultural society. Police \& Society, 7.

Foot, D. (1996). Boom, bust \& echo: How to profit from the coming demographic shift. Toronto, Canada: Macfarlane Walter \& Ross.

Frank, C., \& Tait, S. (2005). Police transformation and accountability in South Africa. In Open Society Institute, Justice Initiatives - Human Rights and Justice Sector Reform in Africa: Contemporary Issues and Responses (February 2005, pp. 14-18). Retrieved June 14, 2005, from

http://www.soros.org/resources/articles_publications/publications/justice_20050207/Justic e_africa.pdf

Geddes, J. (2005, March 28). Why does CSIS destroy its wiretap tapes? Maclean's, 118(13), 16. Harriott, A. (2000). Police and crime control in Jamaica: Problems of reforming excolonial constabularies. Barbados: University of the West Indies Press.

Hermer, J., Kempa, M., Shearing, C., Stenning, P., \& Wood, J. (2005). Policing in Canada in the twenty-first Century: Directions for law reform. In D. Cooley (Ed.), Re-imagining policing in Canada (pp. 22-91). Toronto, Canada: University of Toronto Press.

Hinton, M. (2005). A distant reality: Democratic policing in Argentina and Brazil. Criminal Justice, 5(1), 75-100.

Hutchinson, S., \& O'Connor, D. (2005). Policing The New Commons: Corporate security governance on a mass private property in Canada. Policing \& Society, 15(2), 125-144.

Independent Commission on Policing for Northern Ireland. (1999). A new beginning: Policing in Northern Ireland. London: HMSO. 
Johnston, L., \& Shearing, C. (2003), Governing security:

Explorations in Policing and Justice. London: Routledge.

Jones, T. (2003). The governance and accountability of policing. In T. Newburn (Ed.), Handbook of policing (pp. 603-627). Cullompton, UK: Willan.

Jones, T., \& Newburn, T. (1998). Private security and public policing. Oxford, UK: Clarendon Press.

Kempa, M., Stenning, P., \& Wood, J. (2004), Policing communal spaces: A reconfiguration of the 'mass private property' hypothesis. British Journal of Criminology, 44(4), 562-581.

Kinnear, D. (2000). Privatization: A threat to public police and the public good. In J.

Richardson (Ed.), Police and private security: What the future holds (pp. 108-116). Ottawa, Canada: Canadian Association of Chiefs of Police.

Law-enforcers on the rampage. (2005, April 9). The Economist, p. 35.

Leman-Langois, S. (2000). Constructing post-conflict justice: The South African truth and reconciliation commission as an ongoing invention of reconciliation and truth. Unpublished doctoral dissertation, University of Toronto, Canada.

Leman-Langlois, S. (2002). Constructing a common language: The myth of Nuremberg in the problematization of post-apartheid justice. Law and Social Inquiry, 27(1), 79-100.

Linden, R. (1989). Demographic change and the future of policing. In D. Loree (Ed.), Future issues in policing: Symposium proceedings (pp. 111-127). Ottawa, Canada: Minister of Supply and Services Canada.

Linden, R. (2000). The impact of demographic change on crime and security. In J. Richardson (Ed.), Police and private security: What the future holds (pp. 164-175). Ottawa, Canada: Canadian Association of Chiefs of Police.

McLaughlin, E., \& Murji, K. (2001), Lost connections and new directions: Neo-liberalism, new public managerialism, and the 'modernization' of the British police. In K. Stenson \& R. Sullivan (Eds.), Crime, risk and justice: The politics of crime control in liberal democracies (pp. 104-121). Cullompton, UK: Willan.

Obst, G. (2000). The perspective of the general duty police officer. In J. Richardson (Ed.), Police and private security: What the future holds (pp. 80-82). Ottawa, Canada: Canadian Association of Chiefs of Police. 
Ontario, Strategic Planning Committee on Police Training and

Education. (1992). A police learning system for Ontario: Final report and recommendations. Toronto, Canada: Ontario Ministry of the Solicitor General.

Prenzler, T. (2002). Corruption and reform: Global trends and theoretical perspectives. In T. Prenzler \& J. Ransley (Eds.), Police reform: Building integrity (pp. 3-23). Sydney, Australia: Hawkins Press.

Richardson, J. (Ed.). (2000). Police and private security: What the future holds. Ottawa, Canada: Canadian Association of Chiefs of Police.

Rigakos, G. (2002). The new parapolice: Risk markets and commodified social control. Toronto, Canada: University of Toronto Press.

Shapland, J., \& Van Outrive, L. (Eds.). (1999). Police et securité: Contrôle social et interaction public/privé. [Policing and security: Social control and the public/private divide]. Paris: Editions L'Harmattan.

Shearing, C. (Ed.). (1981). Organizational police deviance: Its structure and control. Toronto, Canada: Butterworths.

Shearing, C., \& Stenning, P. (1982). Snowflakes or good pinches? Private security's contribution to modern policing. In R. Donelan (Ed.), The maintenance of order in society (pp. 96-105). Ottawa, Canada: Minister of Supply and Services Canada.

Shearing, C., Stenning, P., \& Addario, S. (1985), Police perceptions of private security. Canadian Police College Journal, 9(2), 127-153.

Sherman, L. (1978). Scandal and reform: Controlling police corruption. Berkeley, CA: University of California Press.

Spitzer, S., \& Scull, A. (1977). Privatization and capitalist development: The case of the private police. Social Problems, 25, 18-29.

Stenning, P. (in press). The idea of the political 'independence' of the police: International interpretations and experiences. In M. Beare \& T. Murray (Eds.), Police governmental relations. Toronto, Canada: University of Toronto Press.

Stenning, P., \& Shearing, C. (1980), The quiet revolution: The nature, development and general legal implications of private security in Canada. Criminal Law Quarterly, 22, 220248. 
Stenning, P., Shearing, C., Addario, S., \& Condon, M. (1990).

Controlling interests: Two conceptions of order in regulating a financial market. In M.

Friedland (Ed.), Securing compliance: Seven case studies (pp. 88-119). Toronto, Canada:

University of Toronto Press.

Strang, H., \& Braithwaite, J. (Eds.), (2001), Restorative justice and civil society. Cambridge, UK: Cambridge University Press.

Tilley, N. (2003). Community policing, problem-oriented policing and intelligence-led policing. In T. Newburn (Ed.), Handbook of policing (pp. 311-339). Cullompton, UK: Willan.

Walker, S. (2005). The new world of police accountability. Thousand Oaks, CA: Sage.

Wall, D. (2002). Insecurity and the policing of cyberspace. In A. Crawford (Ed.), Crime and insecurity (pp. 186-209). Cullompton, UK: Willan.

Wong, K. (2004). Govern police by law (Yifa Zhijing) in China. Australian and New Zealand Journal of Criminology, 37(Suppl.), 90-106.

Wood, J. (2000). Reinventing governance: A study of transformations in the Ontario provincial police. Unpublished doctoral dissertation, University of Toronto, Canada. 